\title{
Recent advances in the concept of adaptation to natural odour signals in the honeybee, Apis mellifera L
}

\author{
C Masson 1, MH Pham-Delègue 1, C Fonta 1, J Gascuel 1, \\ G Arnold 1, G Nicolas 1, M Kerszberg 2 \\ IINRA-CNRS (URA 1190), Laboratoire de Neurobiologie Comparée des Invertébrés, \\ 91440 Bures-sur-Yvette; \\ 2 CNRS (URA 1284) Laboratoire de Neurobiologie Moléculaire, \\ Institut Pasteur, 75015 Paris, France
}

(Received 14 December 1992; accepted 15 March 1993)

\begin{abstract}
Summary - In this paper we present and discuss a number of experimental results collected from varied and complementary approaches, all aimed at a better understanding of how complex food odour mixtures are processed and discriminated in the bee's olfactory system, and used finally as a flower species-specific signal for foraging behaviour. Several levels have been considered, from developmental and behavioural to neural correlates, including theoretical modelling aspects. We show how the study of this problem, which is exceedingly difficult when considered at the neural level alone, is clarified from being placed in the context of natural environmental conditions, especially with respect to the chemical composition of the flower scent and the related conditioned behavioural responses. In such a framework, the antennal lobe neurones and glomeruli have been subject to intense scrutiny, in terms of morphology, connectivity and response profiles. The data collected so far underline the important role of the antennal lobe in odour decoding.
\end{abstract}

olfaction / odour discrimination / information processing / antennal lobe / ontogenesis / behavioural plasticity

\section{INTRODUCTION}

The search for the neural mechanisms of behavioural plasticity and adaptation constitutes a particularly fascinating field in neurobiology. In many animal species, crucial behaviours for survival are largely dependent on olfactory cues spread over the lifespan; these provide interesting pos- sibilities for studying neurobehavioural plasticity. Here, olfaction of the honeybee Apis mellifera $\mathrm{L}$ constitutes a particularly appealing biological model system, allowing complementary approaches at different levels of organisation, including the developmental aspects, and taking into account the cellular level in a close relationship with the whole organism and its 
behaviour (fig 1). Thus, from their brood cell life to their adult free-flying phase, honeybees are successively and complementarily subjected to a number of different olfactory cues, whose sources more or less overlap in their immediate surroundings (eg chemicals emitted from brood, nestmates, stored food, floral sources). Over its lifetime, the honeybee is actually faced with olfactory surroundings which increase in complexity and spread over an ever larger spatial range. Simultaneously, the relative ratio between intraspecific (eg pheromones) and interspecific (eg food odours) semiochemicals evolves with ageing: thus, during its embryonic and postembryonic development, which takes place in the brood cell, the honeybee is closely surrounded by a qualitatively and quantitatively limited and stable (predictable), odorous environment mainly com- prised of species-specific chemicals. Then, after emergence, the adult is first exposed to the hive odours including nestmate odours (eg queen pheromones), and food odours (eg stored nectars and pollens). Finally, after its first orientation flight, the honeybee is subjected to a huge variety of odour signals, among which multiple, complex and unstable (unpredictable) flower aromas constitute the majority, although particular pheromones still control a number of behavioural sequences.

Honeybee foraging behaviour relies on both an individual learning process of flower-specific signals which occurs at the food source, and a communication process between congeners in the hive (von Frisch, 1967; Wenner and Johnson, 1967; Masson, 1983, 1988). Individual learning is based on an associative conditioning in which the plant chemical signals appear as

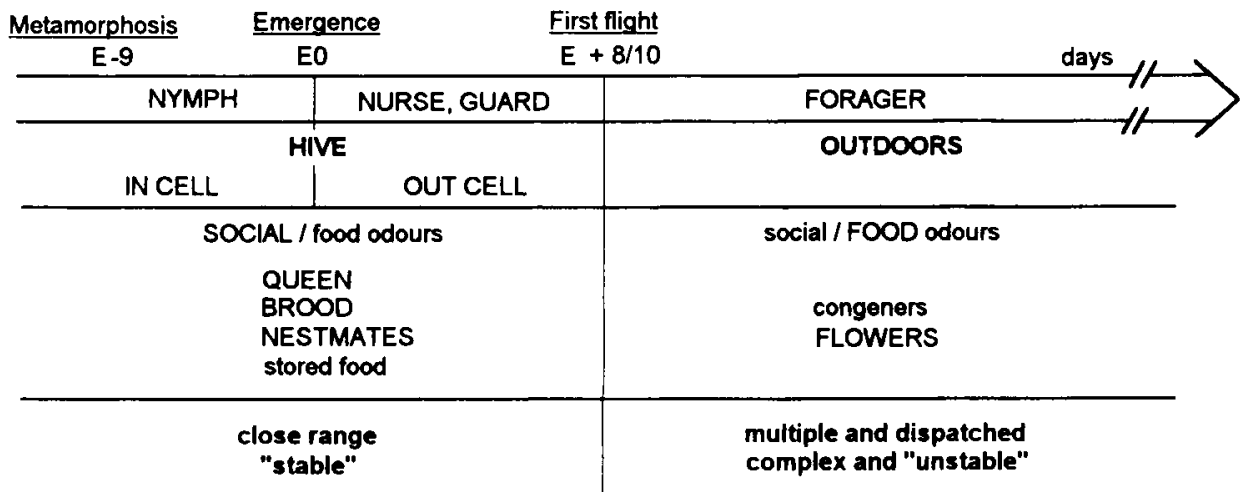

PREDICTABLE ODOUR SURROUNDING

UNPREDICTABLE ODOUR SURROUNDING<smiles>CCOC(=O)c1ccccc1</smiles><smiles>CCCC</smiles>

CHOICE

Fig 1. Comparative fluctuations in the quality of odour signals and in honeybee behaviour. While the bee develops from the pupal to the adult stages, the relative ratio between intraspecific and interspecific odour signals changes with time, evolving from a close range and social odour surroundings towards an odour-rich environment composed of several dispersed sources in which food aromas are particularly important. Consequently, when the odour cue is mainly predictable, no choice is necessary and behaviour is essentially stereotyped. By contrast, while odour sources increase in complexity they become more and more unpredictable, and only an adaptive behaviour (resulting in a choice), allows the bee to accurately select the adequate odour signal (ie, food odour). 
especially efficient, and enable the bee to identify the plant as a whole entity after only one odour-reward association (von Frisch, 1967; Kolterman, 1973; Masson, 1983; Menzel, 1985; Pham-Delègue and Masson, 1985). Natural plant odours are complex volatile mixtures in which components may fluctuate qualitatively and quantitatively (Etievant et al, 1984; Sinclair, 1984). Nevertheless, worker honeybees are capable of accurately foraging the same plant species, regardless of the changes which occur in its aromatic pattern (Pham-Delègue et al, 1989). This suggests generalisation abilities and mechanisms leading to discrimination of the behaviourally relevant stimulus in the midst of a complex and partially unpredictable odorous environment.

Much attention has been focused on the neurobiological processes underlying learning and the formation of memory in honeybees (Mauelshagen, 1990; Mauelshagen and Greggers, 1993; Menzel, 1993). In this context, the study of the neural correlates of odour learning and memory have led to the proposal that both the antennal lobe of the deutocerebrum and the mushroom bodies of the protocerebrum are implicated (Menzel et al, 1974; Erber, 1981). The specific associative components of the olfactory memory trace appear to be essentially localised in the mushroom bodies, the antennal lobes being the location of the non-associative memory. In addition, nonassociative and associative memory components might be separated into 2 parallel structures (Menzel et al, 1991).

Unfortunately, no precise data are available on how and where odour signals may be transformed to produce codes that are suitable for storage in memory. We have therefore addressed the following central questions: how are complex food odour mixtures processed and discriminated by the bee brain into flower-species-specific signals for foraging behaviour? Are the mechanisms whereby this perceptual feat is accomplished totally or partially separated from those leading to memory formation? We investigated different aspects of olfaction in adult and developing honeybees from signal characterisation to the resulting behaviour. The role of plant odours has been extensively investigated through. combined behavioural and chemical approaches (eg Pham-Delègue et al, 1989; 1991a; 1992). Moreover, in order to determine more precisely the role of the antennal lobe in odour-processing and discrimination, the organisation and functioning of its interneurones and glomeruli have been studied in the adult (Arnold et al, 1985; Arnold and Masson, 1987; Fonta et al, 1989; 1991; 1993; Gascuel and Masson, 1991a, b; Sun, 1991; Sun et al, 1993; Nicolas et al, 1993), and a formal model based on these results had been built (Kerszberg and Masson, 1990, 1993; Masson and Kerszberg, 1991). Simultaneously, the developing system has been investigated (Arnold and Masson, 1983; Masson and Arnold, 1984, 1987; Gascuel and Masson, 1991c; Gascuel et al, 1991), aiming in particular at an evaluation of the respective roles of genetic and epigenetic factors both in neural events (Gascuel and Masson, 1987, 1991C; Masson and Arnold, 1987) and behaviour (Pham-Delègue et al, 1990b, 1991b). We present and discuss here a number of the results so far collected which we considered as illustrative of the concept of adaptation to natural odour signals in the honeybee.

\section{BEHAVIOURAL STUDIES ON ODOUR DISCRIMINATION OF FLORAL VOLATILES}

Only a global approach to the planthoneybee relationship, taking into account both partners - through combined behavioural studies of foragers and analysis of 
the signals cueing this behaviour -, may lead to identification of the appropriate plant cues responsible for honeybee's visits and to an analysis of the mechanisms underlying discrimination of complex plant odours. Few studies (Loper et al, 1974; Waller et al, 1974; Robacker et al, 1982) have been developed in such a broad context. Therefore, to further investigate the behavioural discrimination abilities of honey bees among volatiles in order to elucidate the mechanisms by which bees are likely to recognise a complex plant signal, we have conducted a set of experiments, focussed on the chemical signals of 2 crop plants, the sunflower (PhamDelègue et al, 1991a), and more recently, oilseed rape (Pham-Delègue et al, 1992, 1993).

In sunflower, hybrid seed production is strictly dependent on the transport of pollen by honeybees from the male parent to the male-sterile (female) parent (Radford and Rhodes, 1978; Parker, 1981). Field observations indicate that foragers might exhibit preferences between parent genotypes (Freund and Furgala, 1982). Although such behaviour may compromise optimal hybrid seed yield, interestingly, it might be especially useful to decipher the parameters responsible for such behavioural selectivity.

On this crop, although foraging preferences appeared to be dependent upon food availability and quality, nectar being the key factor (Fonta et al, 1985; PhamDelègue et al, 1985, 1991a), honeybees were shown to discriminate the preferred genotype at a long-range distance (PhamDelègue et al, 1985). This suggests that long range recognition among genotypes might be based upon differences in aromatic patterns. Plant volatiles possibly involved in foraging preferences were therefore studied (Etievant et al, 1984; PhamDelègue et al, 1986, 1989, 1990a, b). The aim was first to define possible cues for in- tergenotype discrimination and to investigate the qualitative specificity of sunflower volatile blends.

As regards the genotypic effect, it was shown that differences among pairs of genotypes are restricted to $<10 \%$ of the volatile blend (Pham-Delègue et al, 1990a; 1991a). This indicates that honeybees' discrimination abilities allow them to use a limited range of chemicals to identify the most rewarding food source, and consequently to discriminate between plant genotypes such as the female line of any sunflower genotype versus the corresponding male line. So the honeybee seems to adapt its behaviour to both qualitative and quantitative fluctuations in floral cues, related for example to plant genotypes or plant phenology (Pham-Delègue et al, 1989).

In addition, foraging behaviour was observed in a flight room using an artificial flower feeder device (Pham-Delègue and Masson, 1985). Olfactory choices performed by foragers after a conditioning procedure in which honeybees were presented a food source scented with sunflower extracts were recorded (PhamDelègue et al, 1986). During the testing trials, honeybees were offered a choice between differently scented sources without food; from their selective visits, it was possible to screen out fractions of the complex volatile blend that elicited the recognition of the total extract initially experienced. Thus, in a complex blend containing several tens to hundreds of compounds (Etievant et al, 1984), only a limited fraction $(\approx$ $10 \%$ of the entire aroma) is needed for the recognition of the total volatile blend. In other words, in a behavioural context, the recognition of the plant appears to be based on a simplified pattern of its total aroma.

Parallel works using the GC-EAG method with sunflower extracts as stimulus (Thiery et al, 1990), showed that most of 
the components inducing peripheral sensory responses were not defined as behaviourally active, suggesting the possible action of a selectivity mechanism in the central nervous system.

Consideration of the honeybee-plant relationship in which both partners have been placed in a context close to natural conditions has clearly demonstrated that the honeybee is capable of adapting its behaviour to select and discriminate the right odour signal at the right time. This behaviourally-significant plant odour signal appears to consist of a limited range of compounds which may be referred to as an odour object identified at a perceptual level.

Is this limited blend analysed in terms of individual components? This question was addressed by Getz et al who explored the olfactory perception by honeybees to odour mixtures including both specific and general odours (Getz and Smith, 1987, 1991). Considering the qualitative aspects and those aspects related to the stimulus intensity, all other available data refer to the recognition of pure odorants, often not even a part of the natural environment of the honeybees (von Frisch, 1919; Schwartz, 1955; Koltermann, 1969; Vareschi, 1971; Kramer, 1976; Marfaing et al, 1989). In order to investigate the mechanisms underlying mixture recognition, we have conducted experiments using the conditioning proboscis extension response as a bioassay (Pham-Delègue et al, 1992). As conditioning and testing stimulus, a set of components previously identified as being oilseed rape floral volatiles (Blight et al, 1992) were used, presented either individually or in a synthetic mixture (PhamDelègue et al, 1993).

In this manner, qualitative and quantitative discrimination versus generalisation abilities of honeybees among odour mixtures was investigated. On a qualitative level, the results were consistent with the previous data (Pham-Delegue et al, 1986) suggesting that the recognition of a floral blend relies on a limited range of odour components. A hierarchy within the range of components tested was shown, some components being more representative of the mixture, as also suggested by Getz and Smith (1987) who reported that bees might relate binary mixtures to the constitutive components. In addition, the honeybees were shown to discriminate a learned odorant among others, which is consistent with the studies demonstrating honeybees' ability to memorise pure odorants (von Frisch, 1919; Kolterman, 1969), and with the results of differential conditioning experiments (Bitterman et al, 1983). The specificity level in the recognition of the learned odourant appeared to vary according to the component, as also shown by von Frisch (1919) and Vareschi (1971). Consistently, Smith (1991) found that the response to an odourant after conditioning was not always specific to the conditioned odourant.

On the intensity level, a conditioning threshold has been established below which a reliable conditioning cannot be obtained. This had already been mentioned for different odorants in free-flying bees (Waller et al, 1974; Pham and Masson, 1985), and for the proboscis extension conditioning (Vareschi, 1971). Moreover, recognition thresholds, ie, a range of concentrations higher or lower than that previously experienced allowing the recognition of the conditioning stimulus were found. Interestingly, at this behavioural level variations in generalisation abilities have been observed at the qualitative (Koltermann, 1973; Getz and Smith, 1987; Smith and Menzel, 1989; Smith, 1991), and also at the quantitative level (Getz and Smith, 1991). The chemical structure of the odour components used is nevertheless often incriminated (Smith and Menzel, 1989; Getz 
and Smith, 1991; Smith, 1991), as extensively discussed by Smith (1991); a number of other parameters might also affect the responses, such as the genetic origin of the individuals tested (Koltermann, 1973), the number of conditioning trials, or the temporal latency between conditioning and recall experiments.

Thus, such work taking into account the natural environmental constraints is relevant to the study of odour discrimination and adaptation in honeybees. The different results so far obtained through experi- ments developed on a global level and at a more analytical level underlined the marked ability of the honeybee to generalise with regard to the qualitative and the quantitative aspects of the odour signal.

Interpreted in an ecological context, such generalisation abilities may help the honeybees to forage better on floral sources, even though the odour stimulus encountered is not exactly the same as the conditioning stimulus experienced on other plants or during previous flights (Smith, 1991).

\section{(A) Natural complex plant mixture}
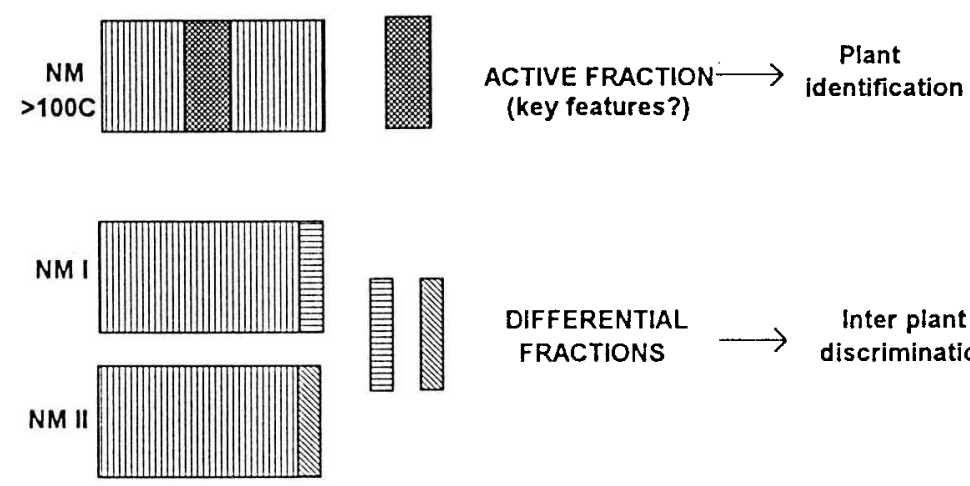

DIFFERENTIAL
FRACTIONS

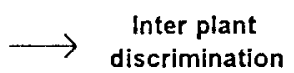
discrimination

B Synthetic simplified plant mixture

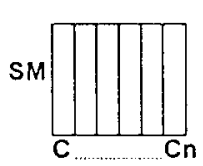

$\begin{array}{cc}\text { Conditioning } & \text { Testing } \\ \mathrm{SM} & \mathrm{Ci} \\ \mathrm{Ci} & \mathrm{SM} \\ \mathrm{Ci} & \mathrm{Ci}\end{array}$

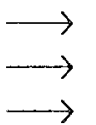

Deneralization

Confusion / Discrimination

Fig 2. Hypotheses on the behavioural discrimination of floral volatile mixtures. (A) Bees conditioned to a natural plant mixture (NM) (eg sunflower) containing tens to hundreds of components $(\mathrm{C})$ are able to identify the learnt mixture from a limited range of components acting as key features in an active fraction of the initial mixture. When comparing 2 plant volatile mixtures (NM I and NM II) (eg aromas of 2 sunflower genotypes), although chemical differences are restricted to differential fractions containing only a few components, bees may use such differences for inter-plant discrimination in order to forage on the most rewarding plant. (B) When using a synthetic mixture of floral volatiles (SM) (eg oilseed rape) and its individual components $(C, \ldots . . \mathrm{Cn}$ ), conditioning bees to $\mathrm{SM}$ and testing to $\mathrm{Ci}$ shows that $\mathrm{Ci}$ may induce responses equivalent to those obtained with the learned SM. This underlines bees olfactory generalisation abilities. In the reverse experiment, where the bees are conditioned to $\mathrm{Ci}$ and then tested to $\mathrm{SM}$, it appears that $\mathrm{Ci}$ is well recognised although present in the mixture. This emphasises bee olfactory discrimination abilities. Finally, conditioning to $\mathrm{Ci}$ and testing successively the learnt $\mathrm{Cl}$ and the other $\mathrm{C}$ leads to different recognition levels of the learnt stimulus. Thus different patterns of confusion or discrimination of the tested $\mathrm{C}$ appear according to its nature. 
Considered from a neurobiological point of view, the mechanisms underlying such odour discrimination and generalisation processes have now to be considered. Since it has been shown that only a reduced fraction of the floral bouquet is behaviourally active, we may assume that it is among such an active fraction that key-features likely to represent codes for memory storage and recall, have to be investigated. How and where in the honeybee brain the significant odour object is discriminated, selected, to be finally compared to the whole blend first experienced is certainly not a trivial question. We have first tentatively investigated this problem at the antennal lobe level.

\section{NEURONAL BASES OF ODOUR DISCRIMINATION}

\section{The olfactory network}

As previously suggested, in a behavioural context such as foraging, discrimination among complex odours is actually the result of a memory process involving storing and recall signals, ie, key-features, representative of the plant aroma. The crucial role of the mushroom bodies in such a memory process is unquestionable (Menzel et al, 1974; Masson, 1977; Erber et al, 1980; Erber, 1981; Menzel, 1983; Getz and Chapman, 1991). The study of the neural correlates of such mechanisms requires determination of how the olfactory system successively analyses an odour at each stage of the network (namely, receptor cells, antennal lobe interneurones and glomeruli, mushroom bodies), and then a comparison of the successive olfactory images. In other words, how information carried by external signal molecules is transformed into patterns of brain activity that underlie odour perception constitutes the central question. In this context, unfortunately, most of the basic mechanisms on coding and processing of single odours and simplified odour mixtures are still poorly documented. Consequently, the processing of food odours in the honeybee olfactory network is far from being understood.

\section{The antennal lobe}

The choice of the antennal lobe was motivated by its crucial position in the olfactory pathway, due to its possible implication as integrative odour centre, where the construction of a spatial and collective representation of the initial odour image encoded in the receptor cells appears to occur. Here, an identification of the decoded signal may be carried out in the background noise, some particular features might be selected and transferred to the mushroom bodies where a new odour representation might be constructed in a behavioural context.

Based on the data now available, a diagram of the organisation of the antennal lobe layer of the bee olfactory network can be proposed (fig 3 ).

The huge majority of antennal sensilla in the worker bee are olfactory (circa 95\%) (Esslen and Kaissling, 1976); unfortunately, few data concerning their cellular physiological properties are available (Lacher, 1964; Vareschi, 1971; Akers and Getz, 1992). As a consequence, the way in which odours are encoded, especially the manner in which the peripheral system discriminates between related olfactory stimuli, remains to be clarified (Getz and Akers, 1993). Nevertheless, in the honeybee, as postulated elsewhere (Selzer, 1981) for non-pheromonal stimuli (eg food odours), due to a certain overlap in the degree of receptor cell responses - each cell responding to a different degree to a range 
of odour molecules -, the peripheral representation of an odour signal (peripheral olfactory image) might be due to complex across-fibre coding schemes (Erickson, 1973, Holley and MacLeod, 1977; Masson and Mustaparta, 1990).

Sensory axons convey encoded olfactory signals to 2 categories of neurones, namely local and output antennal lobe interneurones. Some aspects of the bee local (Flanagan and Mercer, 1989a; Fonta et al, 1989, 1991), and output (Homberg, 1984; Fonta et al, 1989, 1991) antennal lobe interneurones extracellularly recorded in response to odours and other stimuli (eg mechanical, visual), have been investigated. Thus, a number of morphological characteristics and multimodality of output neurones, together with morphological categories of both local and output neurones have been established. In addition, several contributions have demonstrated that the connections between receptor cell axon terminals and antennal lobe interneurones are localised in the antennal lobe glomeruli (Pareto, 1972; Mobbs, 1982, Arnold et al,
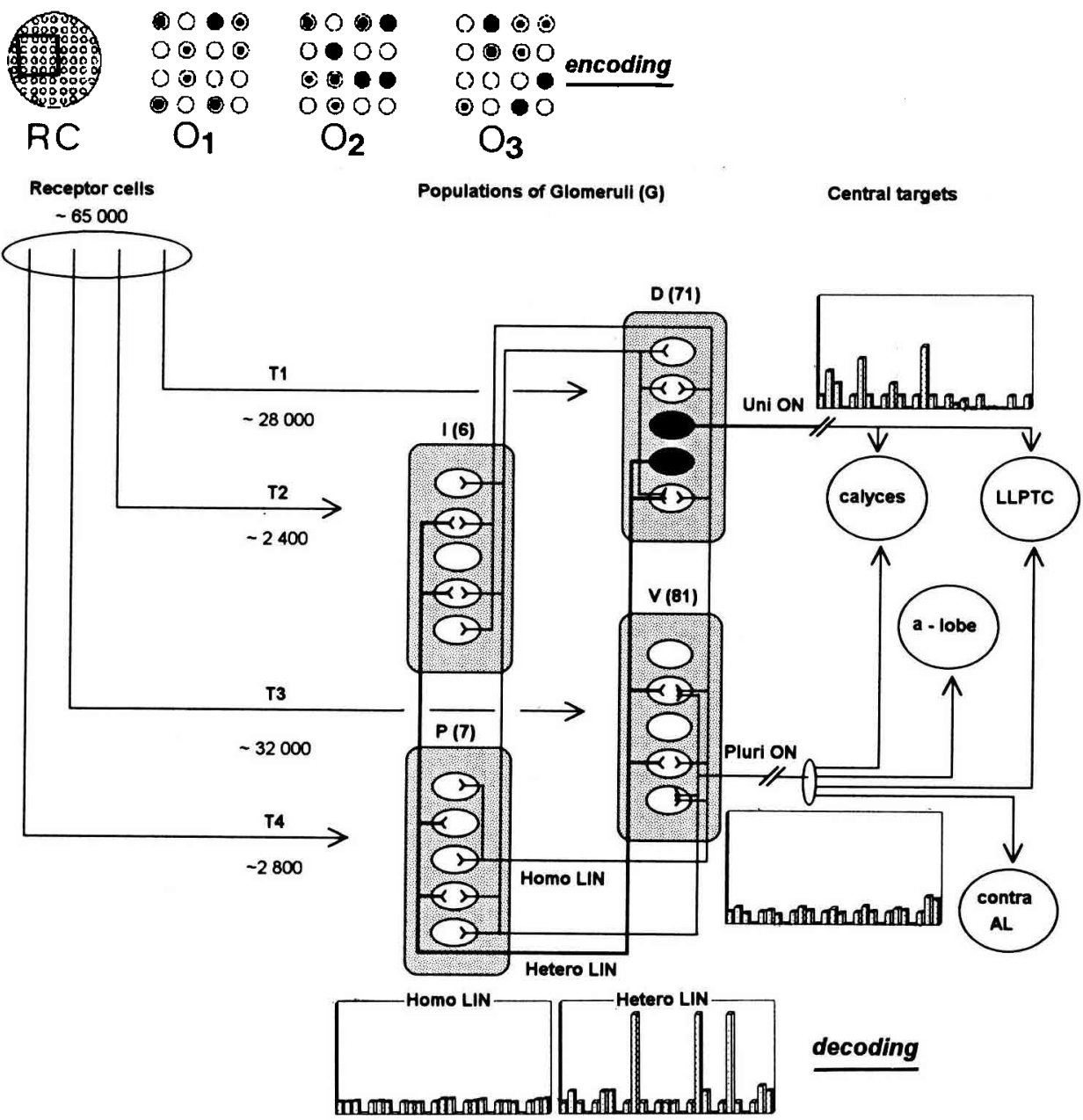
1985; Flanagan and Mercer, 1989a, b; Fonta et al, 1989; 1991; 1993; Gascuel and Masson, 1991a, b), each glomerulus representing an invariant and identifiable morphological neuropilar sub-unit $(\approx 165$ for the worker honeybee) (Arnold et al, 1985).

Such organisation in the antennal lobe connectivity would facilitate the study of the spatial and temporal representation of odours at this stage of the olfactory pathway, and help to better understand which messages might be transferred from the antennal lobe to the upper brain areas. In this context, questions which mainly concern relationships between architecture and function together with the relative contribution of the different components in the processing of the mixtures must be investigated. Thus, we first attempted to characterise the physiological properties of both local and output antennal lobe inter- neurones, analysing and comparing intracellular response parameters of morphologically identified neurones to several single odour components (encoded by supposedly distinct receptor cell types according to Vareschi, 1971), and to the artificial mixtures they may compose (Sun, 1991; Sun et al, 1993; Fonta et al, 1993). Of the results so far obtained, those which are especially relevant to the general content of this paper are briefly reported on below.

Local interneurones constitute the majority of the neurones in the lobe $\quad \approx 90 \%$ of the neurones sampled), and each category of local and output antennal lobe neurones can be subdivided into 2 main types which differ in morphology and spatial distribution of their branching patterns within the glomeruli, and in overall antennal lobe volume. So, whereas all local interneurones are pluriglomerular, the majority of them

Fig 3. Organization of the bee antennal olfactory pathway: architecture connectivity and functional aspects. Regarding architecture and connectivity, in the worker bee $\approx 95 \%$ of $\approx 65000$ receptor cells (RC) appear to be olfactory (Esslen and Kaissling, 1976); the number of antennal lobe interneurones has been estimated at $\approx 5000$ (Witthöft, 1967). Synapses between RC axon terminals and antennal lobe neurones are concentrated inside $\approx 165$ glomeruli $(G)$ (Arnold et al, 1985) with a calculated number of $\approx 40000$ synapses per glomerulus (Gascuel and Masson, 1991b; Masson and Kerszberg, 1991). Glomeruli are spatially organized into 4 populations (D: dorsal, 71G; V: ventral, 81G; I: intermediate, 6G; P: posterior, 7G) each representing the target for one of the 4 sensory tracts (T1, T2, T3, T4) (Arnold et al, 1985; Gascuel and Masson, 1991b). The sample of intracellularly identified antennal lobe neurones indicates that output neurones (ON) are 9-fold less than local interneurones (LIN, $90 \%$ of the antennal lobe neurones) (Fonta et al, 1993). All these data lead to a calculated convergence ratio of $\approx 150 \mathrm{RC}$ per $\mathrm{ON}$. LIN and $\mathrm{ON}$ are both composed of 2 types of neurones which differ in their branching patterns within G: all LIN are pluriglomerular (Hetero LIN and Homo LIN), $80 \%$ of them (Hetero LIN) express a high dense neurite arborisation in one particular G; Pluri ON are pluriglomerular whereas Uni ON invade only one G. Axons of Uni ON project only to the mushroom bodies (calyces) and the lateral lobe of the protocerebrum (LLPTC) via the median tract of the antennoglomerular tract (AGT); in contrast, Pluri ON axons follow several AGT tracts and project to various parts of the brain, in the protocerebrum (calyces, $\alpha$-lobe, LLPTC) and the contralateral antennal lobe. Regarding the functional aspects, odour mixtures appear to be mainly encoded ("encoding") through the simultaneous and differential cooperation of a number of RC. For example, regarding a given population of $\mathrm{RC}$, the respective sensory images induced by 3 odour mixtures $(\mathrm{O} 1,02,03)$ appear to be different, with a certain degree of overlapping (see Vareschi, 1971; Masson and Mustaparta, 1990; Akers and Getz, 1992). At the level of the antennal lobe neurones ("decoding"), whatever the complexity and variability of the response profiles to odour signals observed in both LIN and ON, only Hetero LIN and Uni ON express some selective abilities (Sun et al, 1993) (see Hetero LIN and Uni ON histogram versus Homo LIN and Pluri ON histogram). 
$(\approx 80 \%$ ), namely Hetero LIN (Fonta et al, 1991), (or localised local interneurones, Kerszberg and Masson, 1990) differ from the others, ie Homo LIN (Fonta et al, 1991), (or delocalised local interneurones, Kerszberg and Masson, 1990) by a high density of neurite arborisation in one particular glomerulus. Similarly, a part of the output neurones have dendrites invading only one glomerulus (Uni ON, or localised output neurones), whereas the others (Pluri ON, or delocalised output neurones) are pluriglomerular. Moreover, the finest dendrite arborisations are not uniformly distributed within the glomerular space, but organised into a number of dense microaggregates suggesting a sub-organisation in the distribution of the synapses and local microcircuits. As in addition, most of the arborisations are largely distributed among the 4 populations of glomeruli (both local interneurones and output neurones invade many glomeruli: $1 / 3$ to $2 / 3$ and $>$ $50 \%$ of the total number respectively), a broad distribution of the odour-related activity among this complex connectivity may be hypothesised.

Interestingly, responses of the antennal lobe neurones to various odour stimuli (both single stimuli and mixtures), are characterised by complex and relatively flexible intracellular profiles (Sun, 1991; Sun et al, 1993). As already mentioned (Flanagan and Mercer, 1989a), a certain amount of combinatory phases of excitation and inhibition has been observed in the response profiles (very similar to that observed for vertebrate olfactory bulb neurones: Meredith, 1986; Kauer, 1987).

The study of these response profiles in terms of response patterns, selectivity and responsiveness to single odours and mixtures has provided some interesting data. First of all, it should be noted that intracellularly recorded responses to odour mixtures are generally very complex and difficult to interpret from the responses to the single components. However, some results indicate that a mixture suppression phenomenon (Derby and Ache, 1984; De Jong and Visser, 1988) might occur at this level. The response to the mixture may be less marked than the responses to its components, or the neurone might even not respond at all to the mixture although may respond to the components alone. In addition, a tendency to select particular odourrelated information (ie, a certain amount of selectivity (very low) of response toward one particular pure component) is only expressed in the category of localised antennal lobe interneurones (both local and output). By contrast, both delocalised local and output interneurones are more responsive to mixtures than to pure components (Sun et al, 1993). This might indicate that the related localised glomeruli represent functional subunits which are particularly involved in the discrimination of some key features. Moreover, it is remarkable that although the axons of both types of antennal lobe output neurones project to various areas of the protocerebrum, especially onto mushroom body interneurones where odour memory traces occur (Erber, 1981; Menzel, 1983; Mauelshagen, 1990, 1993), axons of the uniglomerular output neurones are only restricted to the median tract of the antenno-glomerular tract (AGT) (Mobbs, 1982; Arnold et al, 1985), and project only to the mushroom bodies and lateral lobe of the protocerebrum. By contrast, axons of the delocalized output neurones are distributed among several of the AGT tracts; they project to various protocerebral structures, and even to the contralateral antennal lobe (Fonta et al, 1993). These results indicate that a certain degree of topological differentiation might occur in the transfer of some particular odour features from the antennal lobe to the mushroom bodies.

In the hope of correlating the temporal and cellular aspects of odour decoding to 
its spatial and glomerular aspect, the 2DG method (Sokoloff et al, 1977), which has proven a fruitful tool for localising patterns of activity in the olfactory bulb of various mammals (Stewart et al, 1979; Jourdan et al, 1980; Royet et al, 1987; Hudson and Distel 1988), in the antennal lobe of Drosophila (Rodrigues and Büchner, 1984; Rodrigues, 1988), and in homologous olfactory sub-structures in a mollusc (Chase, 1985), has been adapted to the honeybee, aiming at a study of the spatial distribution of odour-related processing in the antennal lobe (Arnold and Masson, 1987). For such a challenge, the bee antennal lobe apparently appears to represent a favourable experimental model system, due to the following: i) its general anatomy (Mobbs, 1982; Arnold et al, 1985) and ultrastructural organisation (Gascuel and Masson, 1991a) are quite well known; ii) each glomerulus represents an invariant and identifiable morphological subunit (Arnold et al, 1985); iii) the afferent olfactory pathway corresponding to each antenna is strongly lateralised up to the mushroom bodies (Masson, 1977; Mobbs, 1984; Arnold et al, 1985), with only few antennal lobe contralateral fibres, which are mainly GABAimmunoreactive (Arnold et al, 1987), allowing in the same insect the use of one antennal lobe with its corresponding antenna as the experimental reference side versus the other antennal lobe, the intact antenna of which is stimulated by the odour flow.

Unfortunately, compared to the data previously reported for other olfactory systems, those so far collected in the honeybee at first proved to be confusing, and it was difficult to make a direct interpretation in terms of odour processing and related odour-patterns of activity through 2DG uptake estimates. One major problem was the high background labelling which characterises the whole antennal lobe in the absence of any particular odour stimulation. So, the activity induced by the appli- cation of the odour stimulus to the ipsilateral antenna must be estimated very carefully against a strong noise source, both in terms of topology and intensity level. Nevertheless, the development of a precise and well adapted method for data analysis has recently led to the establishment of a number of general rules governing 2DG uptake in the antennal lobe independent of the nature of the stimulus (Nicolas et al, 1993, unpublished observations).

Thus, whatever the activity state of the antennal lobe (eg, with or without stimulus application to the antenna), 4 2DG uptake compartments can be identified. The highest labelled area is the periphery of the lobe outside the glomeruli borders, including at least a part of the glial sheath (Gascuel and Masson, 1991a), and the soma of the antennal lobe neurones (Arnold et al, 1985); the external part of the coarse neuropile being much more lightly labelled, whereas the interglomerular spaces and the outer margins of the glomeruli exhibit variable labelling. In addition, quite unexpectedly, the inner glomerular neuropile is generally only slightly or not at all radiolabelled-reactive. In each compartment the labelling is far from uniform; a number of differentially labelled spots suggesting differential levels of activity are observed. Successive measurements have been made all along the periphery of the antennal lobe, in order to locate the sites of highest 2DG uptake. Since glia appears to be the major target for the 2DG uptake, and since the metabolic interactions between neurones and glial cells are well established in the honeybee visual system (Tsacopoulos et al, 1988; Coles, 1989), indirect information on glomerular activity can therefore be obtained. In the periphery of the antennal lobe, even if a range of inter-individual variations occurs, a number of common features in the spatial distribution of loci of highest 2DG uptake can be proposed. Thus, in serial sections high up- 
take spots are not randomly distributed, but often appear as ordered in stripes along the antero-posterior axis of the lobe. Interestingly, such bands of labelling have also been described along the anteroposterior axis of the olfactory bulb in mammals (Astic and Saucier, 1983). Comparison between the stimulated and unstimulated lobes in the same individual, and from one honeybee to the next shows that the odour stimulus does not induce drastic changes in the general topology of 2DG uptake; however, in the ipsilateral (odour stimulated) side as compared to the contralateral side the activity patterns are partly redistributed. Moreover, in the ipsilateral lobe, the intensity of the labelling increases in a number of labelled spots.

The widespread nature of 2DG uptake in the antennal lobe is in agreement with the complex and largely distributed architecture of the antennal lobe interneurones supporting the hypothesis of complex odour-response profiles fluctuating in time (Fonta et al, 1993; Sun, 1991; Sun et al, 1993). Interestingly, the heterogeneous labelling in the defined compartments allows the realisation of functional activity maps and the comparison between activity maps corresponding to different odours. Regarding the qualitative aspect of the odour stimulus, our last results, obtained with several individuals, demonstrate that a correspondence exists between 2 different odour qualities (a mixture, the synthetic queen pheromone (Slessor et al, 1988), and a single compound, geraniol), 2 qualitative activity maps with a certain degree of overlap, the limits of each odour quality map not being precisely delineated from one individual to the next. Thus, the present data suggest that in the antennal lobe, different odour qualities with different biological meaning might be decoded according to separate spatial maps sharing a number of common processing areas. How the differential intensity labelled spots evidenced in such spatial maps contribute to the differential decoding of odours remains to be seen. Experiments now in progress may help us to better understand this important aspect of odour processing at the antennal lobe level.

Thus, a number of physiological parameters as well as morphological and geometrical details concerning the honeybee antennal lobe components are now available; nevertheless, the mechanisms underlying the decoding of odour signals at this stage in the olfactory pathway remain unclear (at the cellular, spatial and temporal levels). Such mechanisms appear to be very complicated and supported by an intricate architecture and connectivity. With regard to the complexity in the responses so far observed, together with the experimental difficulties involved in obtaining strictly reproducible and comparable data, a theoretical approach has been developed. Its aims were to try to make sense of rather inconclusive experimental results and thereby to aid in the planning of further experiments (Kerszberg and Masson, 1990; Masson and Kerszberg, 1991). Interestingly, computer simulations of the model built so far exhibit a rich spontaneous input-free dynamics of the glomerular-interneuronal system. The self-generated partly stochastic activity of individual cells and synapses is the driving force for this autonomous behaviour. A range of remarkable space and time patterns is observed, including strongly and loosely coupled oscillations, and random (possibly chaotic) pulse generation. These various states of the glomerular system arise from interactions between the synaptic and cellular properties, and must evidently be considered as potentially important for information processing. If autonomous activity were always to be so strong, however, applied input signals would be lost in this inherent noise. In order to reveal the effect of input signals on the system, activity must be reduced to 
some extent. Biologically, this may be achieved through the quenching effect of raising the synaptic activation threshold. This is a parameter which, although it must clearly be specified in a stimulation, is nevertheless as yet quite poorly measured electrophysiologically. The spontaneous dynamics of the network then become poorer, but the imposition of external signals (both single inputs and mixture inputs), then leads to observable surges of activity. These it turns out may disclose some of the various spontaneous states hidden under the apparent quiescence due to the quenching effect. What is noticeable, therefore, is not so much the presence of a rich spontaneous activity than the revelation, through the input effect, of the underlying preexistent complexity.

Thus, a number of striking convergences exist between the experimental data (both single cell responses and 2DG mapping) and those of the computer simulations; eg, simulations in the presence of input information indicate a very low specificity similar to that experimentally observed. So, it is possible that if any scent-induced space-time image is present at all this stage in the olfactory pathway, it might be extremely fuzzy and fluctuating. The rules for reading this fuzzy pattern are still unknown. Further processing is required. Theory suggests that an adaptive process must be present to allow for information extraction which might thus occur in the upper brain areas. This fits well with experimental results (Menzel et al, 1974; Erber, 1981). Both experimental and modelling approaches are in progress to further test this hypothesis.

\section{DEVELOPMENTAL CORRELATES}

The data reported above suggest that in the worker bee, the discrimination of odour cues relies on widespread behavioural plasticity and on a complex neural architecture underlying particularly complex and flexible physiological properties of both antennal lobe interneurones and glomeruli. The question now arises of the developmental correlates related both to neural network organisation and behavioural abilities. In this context, programmed (genetic) and non-programmed (epigenetic) factors have to be considered, especially with the aim of further evaluating how the odour environment acts on the developing honeybee (fig 4).

\section{Neural level}

The ontogeny of the antennal afferent pathway takes place during the pupal stage, which begins $9 \mathrm{~d}(\mathrm{E}-9)$ before the emergence time $(E)$ of the adult. During the pupal development the differentiating sensory neurones elaborate dendrites which enter the developing antennal sensilla and send their axons to their target neurones in the ipsilateral antennal lobe (Panov, 1961; Masson and Arnold, 1987). The developing antennal afferent pathway has been investigated by light microscopy (Arnold and Masson 1983; Masson and Arnold 1984, 1987), and transmission electron microscopy (Gascuel and Masson, 1991c). The main results are briefly reported below.

From the 1st $d(E-9)$ to the 3rd d (E-7) of the pupal period, the main antennal sensory bundles reach the antennal lobe, the first glomeruli-like structures, the socalled pre-glomeruli, appear (compared to adult glomeruli they are smaller and without the cortical layer). Concomitantly, a group of AGT fibres is visible and can be followed into the upper brain areas, particularly the mushroom bodies. Between E-7 and $E-4$ AGT is built up, whereas the number of pre-glomeruli increases progressive- 
ly. Three $d$ before emergence (E-3), light microscopy data show that the glomerular organisation of the antennal lobe appears morphologically adult-like (4 populations of glomeruli and their related sensory tracts, parameters characteristic of adult glomeruli, such as their respective shape, volume and cortical layer). By contrast, at the ultrastructural level, the antennal lobe is still immature and characterised by a low synapse frequency. Moreover, the large inter- cellular spaces which are observed at the level of the afferent tracts in the glomeruli and in the coarse neuropile strongly suggest that the neurites are still growing. However, the glial processes already delineate the glomeruli. Ultrastructurally, only 1 $d$ before emergence $(E-1)$, the entire neuropile has an adult appearance.

Interestingly, it has been shown that a significant synaptic rearrangement occurs in the glomeruli, whereas simultaneously

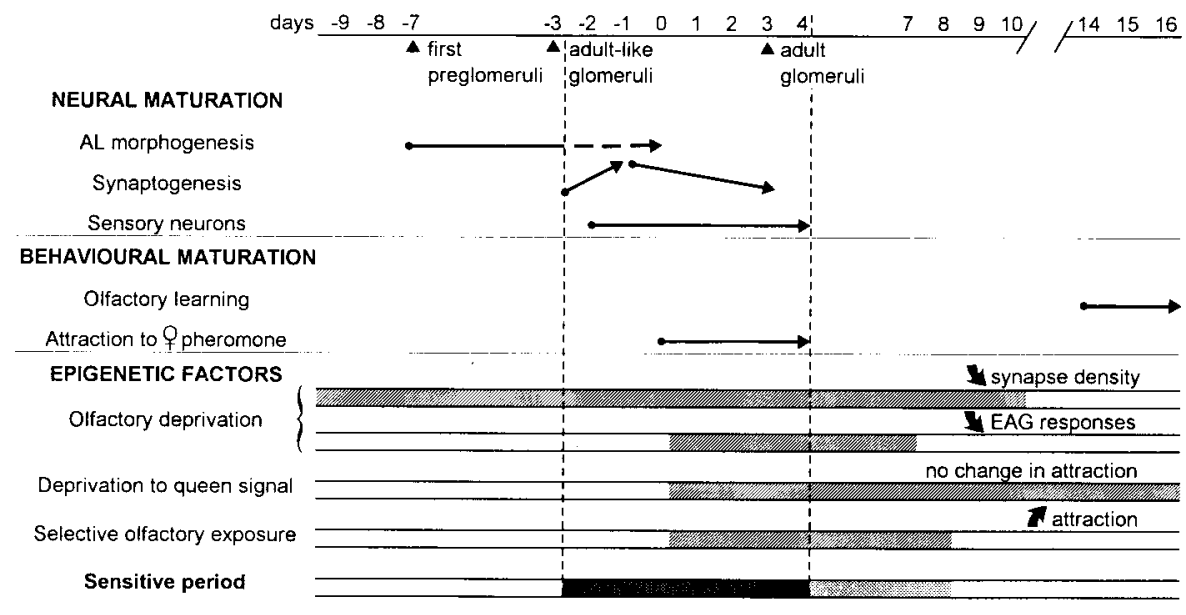

Fig 4. Neural and behavioral developmental events. Maturation processes have been investigatedat the neural and at the behavioural level. At the neural level, i) antennal lobe morphogenesis starts when sensory axons reach the antennal lobe. The first pre-glomeruli are visible at E-7, and the glomerular organisation progressively sets up until E-3 when the glomeruli become adult-like (light microscopy). At this stage, when observed by transmission electron microscopy, the antennal lobe neuropile appears immature. From E-3 to E-1 the neuropile matures, the synapse density increases, and then decreases until $E+3$ when the glomeruli appear adult ; ii) the maturation of sensory neurones lasts from $E-2$ to $E+8$, and slightly overlaps the period when the synapse density decreases. AL: antennal lobe. At the behavioural level i) maximum olfactory learning performances regarding general odours observed from conditioned proboscis extension assay occur at 14-16-d old, when workers are particularly involved in foraging duties; ii) maximum attraction of workers to the queen signal observed from an olfactometer assay occurs at 1-4-d old, consistent with the age when worker's attending behaviour to the queen is described in a colony. The effects of epigenetic factors have been studied by undertaking olfactory deprivation or exposure experiments. At the neural level, olfactory deprivation applied i) from E-9 to $E+10$ results in a synapse density decrease; and ii) from emergence to $E+7$ in a decrease in olfactory sensitivity. At the behavioural level, from olfactometer experiments it appears that deprivation to the queen signal at the adult stage only weakly affects the agedependency of worker responses to the signal, whereas exposure to general odours significantly increases attraction response to the exposure odours only if the exposure lasts for $8 \mathrm{~d}$ after emergence. From these convergent data, it may be assumed that the period lasting from $E-3$ to $E+4$ $(E+8$ ? $) d$ is a sensitive period for both neural and behavioural olfactory-mediated events. 
the functional maturation of the sensory neurones is evidenced. Thus, on the one hand, the synapse density increases from $E-3$ to $E-1$ and then decreases until $E+3$ at which time adult synapse frequency is reached. On the other hand, the receptor cells are first odour-responsive $2 \mathrm{~d}$ before emergence ( $E-2)$. Their sensitivity (measured by $E A G$ ) increases until the 4 th $d$ $(E+4)$ of adult life, the response amplitude at emergence $(E-0)$ being only $30 \%$ of the corresponding value recorded at $E+4$.

Consequently, regarding the antennal lobe, the development of the olfactory pathway can be subdivided into 2 complementary periods, the first lasting from E-9 to E-3 during which the setting up of the main features of the afferent antennal pathway takes place. During the second period lasting from $E-2$ to $E+4$, the maturation processes occur. During the former period, the odorous surrounding is poor (fig 1), and the sensory neurones are still not odour-responsive; therefore, during this period the involvement of environmental factors in the ontogeny of the antennal lobe seems to be excluded, and the role of genetically controlled cell-cell interactions then appears to be dominant (Masson and Mustaparta, 1990). By contrast, during the second period, which constitutes a transition phase between the nymphal and the adult stages, during which the odorous surroundings increase significantly (fig 1), when the receptor cells mature, epigenetic signals could play a role in the setting up of antennal lobe connectivity. Thus, both programmed (cell-cell interactions) and non-programmed (environmental) factors certainly contribute to the organisation of antennal lobe connectivity.

In an attempt to investigate cell-cell interactions the effect of early deafferentation experiments on the developing antennal lobe was analysed. Our results clearly demonstrated the crucial role of the receptor cells. Thus, early deafferentation (at E-
9) prevents the formation of the glomeruli (Gascuel and Masson 1991c), the results are consistent with the hypothesis that the glia are involved in glomerulus formation (Oland and Tolbert, 1988). Moreover, the results demonstrate that the absence of sensory axons not only strongly affects glomerulus formation but that it also affects the neurite arborisation patterns of the antennal lobe neurones inside the glomerulus. The way in which sensory axons act at the molecular level is still unclear in the honeybee, and 2 alternative hypotheses may be considered. Either the sensory axons could interact directly with the antennal lobe neurones to shape the glomeruli, or the effect of sensory neurones could be mediated by the glial cells. At the present time, our results do not permit the determination of which possibility to select. Cell culture experiments currently in progress (Gascuel et al, 1991) might contribute to a better understanding of this important point.

By contrast, deafferentation experiments carried out later, ie, from $\mathrm{E}-3$, have demonstrated normally-shaped glomeruli, similar to those developed in normally afferented insects (Gascuel and Masson, 1991c). Consequently, the basic organisation of the developing antennal lobe seems to be controlled by a cascade of cellular interactions (involving receptor cells, glial cells and antennal lobe interneurones) occurring until $3 \mathrm{~d}$ before emergence, at which time the general glomerular organisation appears to be stabilised and not affected by the absence of sensory axons.

As already mentioned, during the period lasting from $E-3$ to circa $E+4$, the odorous surroundings might be crucial for the connectivity supporting the adult performances to odour cues. Odour deprivation experiments including those connected with the above period have been performed as a preliminary attempt to investigate such an environmental effect on the developing ol- 
factory system. These experiments which result in a decrease in receptor cell responsiveness to different odour signals (Masson and Arnold, 1984), also result in a significant decrease in synapse frequency in the glomeruli (Gascuel and Masson, 1987). Thus, the honeybee olfactory system appears to be extremely flexible in response to environmental changes. In the honeybee, such plasticity is not limited to the olfactory system. Very similar results have been obtained in the visual system in which chromatic deprivation in 2-wk old honeybees also induced a decrease in receptor cell sensitivity and a decrease in synapse frequency in the lamina (Hertel, 1982, 1983). Moreover, other neural correlates to environmental changes have also been reported in the mushroom body where the dendritic spine morphology seems to show rapid modifications in relation to the first orientation flights (Coss et al, 1980, Brandon and Coss, 1982).

\section{Behavioural level}

When examining behavioural plasticity related to developmental aspects 2 approaches can be considered. One consists of studying behavioural maturation processes, which allows genetically-based response changes with age to be shown. The other approach relies on the evaluation of the flexibility of predetermined responses according to experience, leading to the demonstration of adaptive capabilities as regards epigenetic factors. We adopted both approaches to elucidate certain elements of behavioural adaptation in the honeybee.

Under hive conditions, age polyethism of tasks has been extensively described, worker bees evolving from indoor to outdoor duties (Sakagami, 1953; Seeley, 1982). Evidence of adaptive abilities has been found, since age specialisation in tasks among worker honeybees is largely flexible according to the amount of brood stores, or is conditioned by stress conditions (Free, 1965; Winston and Fergusson, 1985; Kolmes and Winston, 1988). The age polyethism of tasks has been described not only under hive conditions, but also under laboratory conditions. Thus, olfactory conditioning of proboscis extension, according to a classical procedure described in honeybees (Takeda, 1961; Bitterman et al, 1983), was shown to be age-dependent, worker bees of 14-16-dold performing best (Pham-Delègue et al, 1990c). It should be noted that at this age, honeybees are supposed to be devoted to foraging duties (Kolmes, 1985), in which their learning abilities are particularly required.

Now, referring to the retinue behaviour induced by the queen, it is known that within the hive, the former is exhibited especially by worker honeybees of < 6-d old (Sakagami, 1953; Allen, 1960; Seeley, 1982). Convergent data have been obtained with known-age honeybees tested in cages (Pham-Delègue et al, 1982), or in an airflow olfactometer (Pham-Delègue et al, 1991b, 1993) using either a natural queen extract or a synthetic queen mixture found to be active in eliciting retinue behaviour (Slessor et al, 1988). Therefore, we may assume that particular behavioural events such a retinue behaviour or foraging activity basically occur at special periods during the lifespan, as shown from experiments under natural conditions in the hive or using laboratory bioassays. More-over, odour exposure applied at a particular phase in development may affect later olfactory-mediated responses. Thus we found that the exposure to a single odorant (geraniol) applied from emergence to 8-d old could significantly increase the behavioural response to this component (Pham-Delègue et al, 1990b). These data suggest the occurrence of a re- 
stricted behavioural period taking place at the early adult stage, where the olfactory environment might induce later behavioural changes to the exposure stimulus. However, such an effect strongly depends on the nature of the odour stimulus itself, since the attraction induced by the queen signal toward worker bees appeared to be weakly affected by prior exposure to that signal (Pham-Delègue et al, 1993). Consequently, behavioural responses following passive olfactory exposure only may be flexible to some extent, depending on the nature of the behaviour and of the stimulus considered (eg stereotyped responses to pheromonal compounds versus learned responses to general odorants), and on the period (sensitive period?) during which the experience occurs. The regulation mechanisms underlying behavioural maturation processes and behavioural plasticity remain largely unknown.

As reported above, EAG recordings showed that the sensory response increases to a maximum by 4-8 d for several pure odorants including pheromonal and general odour compounds (Masson and Arnold, 1984; Allan et al, 1987). Thus, such a maturation phenomenon expressed in the olfactory sensitivity does not seem to be specific for the stimulus tested and appears to be a rather general process. However, for this criterion no direct correlates with behavioural sensitivity can be established, since some stimuli such as the queen signal elicit strong behavioural responses whereas antennal sensitivity to that stimulus is still rather low (PhamDelègue et al, this issue). This leads us to address the question of the neural and neurohormonal control of such behavioural responses and plasticity. In this context, it has been shown that application of juvenile hormone analogue affects behavioural responses to alarm pheromones without inducing a modification in receptor cell sensitivity (Robinson, 1987). By contrast, it has been recently shown that $\mathrm{JH}$ analogue application which results in behavioural changes also results in morphological changes in the honeybee brain structures (ie volume of the antennal lobe and mushroom bodies) (Withers et al, 1992).

When considering adaptive performance toward environmental factors, some convergence between the behavioural sensitive period and the neuronal sensitive period (evaluated at the antennal lobe level) can also be found. Thus, exposure to olfactory stimulus such as geraniol during the first $8 \mathrm{~d}$ of adult life is particularly efficient in modifying the response to the exposure stimulus (Pham-Delègue et al, $1990 \mathrm{~b}$ ), this period being partly included in the period when the final organisation of the antennal lobe layer of the olfactory network occurs (Masson and Arnold, 1984; Gascuel and Masson, 1991c), and during which odour deprivation results in drastic changes in antennal lobe connectivity (Gascuel and Masson, 1987) (fig 4).

Thus, such results (Gascuel and Masson, 1987; Pham Delègue et al, 1990b; Withers et al, 1992) suggest that interesting possibilities for studying neurobehavioural plasticity may emerge from behavioural and neuronal investigations undertaken simultaneously in a developmental context.

\section{CONCLUSION}

In order to better understand how complex odour mixtures are processed and discriminated in the honeybee brain for use in a behavioural context (foraging), we have thus been led to investigate phenomena at various complementary levels, from behavioural to neural correlates and including developmental aspects. Even though any attempt to find narrow correlations between the results so far obtained still con- 
stitutes a hazardous task, a number of convergent data have been obtained which illustrate the variety and plasticity of the honeybee's responses to odours. We have shown how the study of odour discrimination and adaptation benefits from being undertaken in the context of natural environmental conditions (ie plant chemicals and foraging behaviour). The results so far established indicate the means for further investigation phenomena at the neural level. In spite of their complexity, data on architecture and functioning of antennal lobe neurones and glomeruli have enabled computer simulations to be made which contribute to the demonstration of the complex role of this part of the olfactory system in odour decoding. These results represent a solid basis for further experimental and theoretical examination of the basic question: how is the olfactory message perceived and learned?

\section{ACKNOWLEDGMENTS}

We would like to thank $X J$ Sun for invaluable collaboration in the study of the antennal lobe neurones, $F$ Patte for assistance in the 2DG study, and LJ Wadhams for fruitful cooperative work in the study of plant volatile discrimination.

\section{Résumé - Progrès récents dans l'étude de l'adaptation aux signaux odo- rants d'origine naturelle chez l'abeille (Apis mellifera L). Nous avons entrepris des études multidisciplinaires destinées à élucider les mécanismes neuronaux et comportementaux responsables des capa- cités d'adaptation de l'abeille aux modifica- tions des conditions environnementales, en nous basant sur l'étude des réponses de cet insecte à des signaux chimiques complexes (fig 1).}

Des études comportementales de la discrimination olfactive ont été entreprises en utilisant pour stimulus des émissions volatiles florales. L'étude du comportement de butinage, conduite en conditions naturelles et au laboratoire, sur des plantes cultivées telles que le tournesol, associée à l'identification chimique des émissions florales, a montré que :

- les préférences inter-génotypes, liées à la qualité du nectar, étaient établies sur la base d'un nombre limité de constituants discriminatifs au sein des arômes floraux,

- la reconnaissance d'un mélange floral reposait sur une fraction active limitée à moins de $10 \%$ du mélange, la plupart des constituants de la fraction ayant été identifiés chimiquement (fig 2). II apparaît donc que, sur le plan comportemental, la reconnaissance de la plante met en jeu un pattern olfactif simplifié.

D'autres études, utilisant la réponse conditionnée d'extension du proboscis, le stimulus conditionnel étant constitué par un mélange de constituants volatils de colza, ont confirmé l'existence de composés clés impliqués dans la reconnaissance du mélange de conditionnement. De plus, des capacités de généralisation quantitative et qualitative ont été montrées, les abeilles étant capables de répondre à une gamme de signaux différents par rapport au signal de conditionnement.

Au sein du système olfactif, nous avons principalement focalisé notre étude au niveau du lobe antennaire, centre de traitement des informations qualitatives et quantitatives détectées par les neurorécepteurs olfactifs de l'antenne. Deux niveaux structuraux (glomérulaire et cellulaire) ont été étudiés afin d'analyser la représentation spatiale, temporelle et qualitative de l'image olfactive.

À l'aide d'enregistrements intracellulaires et de marquage des neurones du lobe antennaire, nous avons observé 2 principaux types d'inter-neurones locaux(Homo LIN et Hetero LIN) et 2 types de 
neurones efférents (Uni ON et Pluri ON). Les profils de réponse des différents types de cellules présentent des caractéristiques dominantes qui ont conduit à proposer une classification morphofonctionnelle des neurones du lobe antennaire (fig 3 ).

La méthode du 2DG a été utilisée pour étudier la distribution spatiale de l'activité dans le lobe antennaire en réponse à une stimulation odorante. Différents compartiments ont été caractérisés dans le lobe, dans lesquels peuvent maintenant être recherchés des motifs d'activation caractéristiques de différentes odeurs.

Face à la complexité d'une part des réponses cellulaires, et d'autre part de l'architecture et de la connectivité des neurones, une approche théorique a été développée. Les simulations informatiques montrent une riche dynamique spontanée du système glomérules-interneurones. Des oscillations couplées et la génération de pulses aléatoires ont été observées, qui sont interrompues par l'arrivée des inputs. Les approches expérimentales et formelles convergent pour suggérer que l'information olfactive est bruitée au niveau du lobe antennaire et que l'extraction de traits pertinents pourrait se produire à la suite de processus adaptatifs.

Nous avons également étudié l'ontogenèse des réseaux de neurones et des comportements (fig 4), en considérant à la fois le rôle des facteurs programmés et non programmés. II est apparu que, d'une part, le rôle des interactions cellulaires entre neurones sensoriels, neurones du lobe antennaire et cellules gliales est déterminant dans la mise en place de l'organisation générale du lobe antennaire, en particulier dans la formation du glomérule et, d'autre part, les facteurs environnementaux jouent un rôle dans le contrôle de la synaptogenèse, probablement par l'intermédiaire de l'activité des neurones sensoriels.
Les aspects développementaux de la plasticité comportementale ont été analysés selon 2 approches complémentaires. Tout d'abord, pour mettre en évidence des réponses prédéterminées en fonction de l'âge, nous avons analysé les processus de maturation des réponses conditionnées d'extension du proboscis et d'attraction des ouvrières d'abeilles vis-à-vis de la phéromone royale. Puis, nous avons analysé l'effet d'une expérience olfactive sur les réponses comportementales. Les réponses peuvent présenter une certaine flexibilité en fonction de la nature du signal odorant (signal floral versus phéromonal) et de la période d'application de l'expérience olfactive.

olfaction / discrimination olfactive / traitement de l'information / lobe antennaire / ontogenèse / plasticité comportementale

\section{Zusammenfassung - Fortschritte beim Konzept der Anpassung an Duftstoffe bei der Honigbiene. Wir haben fachüber- greifende Versuchsansätze unternommen, um neuronale und Verhaltensmechanis- men aufzuklären, die für die Fähigkeit ver- antwortlich sind, sich an ändernde Umwelt- bedingungen anzupassen. Dazu haben wir Honigbienen als biologisches Modell be- nutzt, die komplexen natürlichen Chemika- lien ausgesetzt waren (Abb 1).}

Wir haben Verhaltensstudien über die Unterscheidung von Duftstoffen durchgeführt, wobei wir Blütenduftstoffe als Stimuli verwendeten. Die Experimente, denen Studien über das Sammelverhalten bei Trachtpflanzen wie zB Sonnenblumen als Grundlage dienten, - beobachtet sowohl im Freiland als auch im Labor - wurden kombiniert mit chemischer Fraktionierung und Identifizierung der Duftstoffe. Dabei zeigte sich : 
- daß die intergenotypische Bevorzugung auf die Qualität des Nektars zurückzuführen war, die Erkennung jedoch auf einer begrenzten Anzahl unterschiedlicher, flüchtiger Komponenten des Blütenduftes beruhte, und

- daß die Erkennung der Duftmischung auf einer aktiven Fraktion von weniger als $10 \%$ der gesamten Duftstoffe beschränkt ist, von der die meisten Komponenten chemisch identifiziert wurden (Abb 2). Demnach beruht die im Verhalten gezeigte Erkennung der Pflanzen auf einem vereinfachten Grundmuster von Duftstoffen. Weitere Versuche, bei denen der Rüsselreflex als Biotest und Duftstoffe vom Raps als konditionierter Reiz dienten, bestätigte das Vorkommen von Schlüsselkomponenten, die zu einer Erkennung der konditionierten Duftkomposition führte. Außerdem zeigte sich durch den Nachweis der Fähigkeit einer quantitativen und qualitativen Generalisierung, daß es Bienen möglich ist, auf eine Reihe von Signalen zu reagieren, die sich vom konditionierten Reiz unterscheiden.

Im neuronalen Netzwerk, das dem Geruchssinn dient, konzentrierten wir uns auf die antennalen Loben, dem Zentrum der Aufnahme von qualitativen und quantitativen Informationen, die von den antennalen Geruchsrezeptoren rezipiert wurden. Zwei strukturelle Ebene (glomeruläre und zelluläre Ebenen) wurden erforscht, um die räumliche, zeitliche und qualitative Repräsentation eines geruchlichen Bildes zu untersuchen.

Intrazelluläre Ableitungen und Färbung von Neuronen der antennalen Loben wurden durchgeführt. Wir beobachteten zwei Haupttypen von lokalen Schaltneuronen (Homo LIN und Hetero LIN) und zwei Haupttypen von Ausgangsneuronen (Uni ON und Pluri ON). Die Antwortprofile von den verschiedenen Zelltypen zeigen auffallende Strukturen, die dazu führten, eine funktionsmorphologische Klassifikation der Neurone im antennalen Lobus vorzuschlagen, die einen räumlichen Zusammenhang bei der Integration und dem Transfer von Information und die relative Fähigkeit der Zelle Informationen auszuwählen, unterstützt (Abb 3).

Die 2DG Methode wurde benutzt, um die räumlichen Aktivitätsmuster in den Glomeruli der antennalen Loben der Honigbienen zu lokalisieren, die durch Duftstoffe stimuliert wurden. Die Ergebnisse zeigen eine räumliche Verteilung von Loci mit höchster 2DG Aufnahme und Aktivitätsfelder, die sich je nach Duftstoffen unterschieden.

Bei Berücksichtigung der Komplexität der Zellen in ihren Antworten, in ihrem Bau und in ihren Verknüpfungen wurde der Versuch unternommen, ein Modell zu entwickeln. Komputersimulationen zeigen die vielfältige spontane Dynamik des glomerulären-interneuralen Systems. Gekoppelte Schwingungen und spontane Entladungen konnten beobachtet werden, die durch die Einwirkung von Eingangsreizen unterbrochen werden. Der experimentelle Ansatz und der Modellansatz führen beide zu der Vorstellung, daß die geruchliche Information ein Rauschen auf dem Niveau der antennalen Loben ergeben und daß die Reizfilterung durch adaptive Prozesse auftritt.

Wir untersuchten auch Korrelationen in der Entwicklung, die sich auf beides beziehen, auf die Organisation des neuralen Netzwerkes und die möglichen Verhaltensreaktionen, und genetische und epigenetische Faktoren wurden in Betracht gezogen. Es zeigte sich auf der einen Seite, daß die Rolle der Zell-Zell-Interaktionen zwischen den sensorischen Neuronen, den Neuronen der antennalen Loben und den Gliazellen entscheidend sind für den Aufbau der Grundorganisation der antennalen Loben und besonders für die Bildung der Glomeruli. Auf der anderen Seite spie- 
Ien Umweltfaktoren bei der Endkontrolle der Entstehung der Synapsen eine Rolle, wahrscheinlich über die Vermittlung der Aktivität der sensorischen Neurone.

Aspekte bei der Entwicklung der Plastizität im Verhalten wurden analysiert, indem zwei komplementäre Ansätze verfolgt wurden. Erstens, um die genetisch abhängigen Reaktionen je nach Alter zu untersuchen, studierten wir die Reifungsprozesse des konditionierten Rüsselreflexes und der Anlockung von Arbeiterinnen auf das Königinnenpheromon. Zum zweiten analysierten wir das Ausmaß des Einflusses von früheren Dufterfahrungen auf Reaktionen im Olfaktometer. Verhaltensreaktionen könnten flexibel sein, abhängig von der Eigenschaft des betrachteten Stimulus (Signal: Blütenduft versus Pheromon) und von der Periode, in der die Erfahrung gemacht wurde.

\section{Geruchssinn / Unterscheidung von Duftstoffen / Antennallobus / Verarbei- tung der Informationen}

\section{REFERENCES}

Akers RP, Getz WM (1992) A test of identified response classes among olfactory receptor neurons in the honey-bee worker. Chem Senses 17, 191-209

Allan SA, Slessor KN, Winston ML, King GGS (1987) The influence of age and task specialization on the production and perception of honey bee pheromones. J Insect Physiol 33, 917-922

Alten MD (1960) The honeybee queen and her attendants. Anim Behav 8, 201-208

Arnold G, Masson C (1983) Mise en place des connexions synaptiques de la voie afférente antennaire au cours du développement nymphal de l'ouvrière d'abeille Apis mellifica ligustica L. C R Acad Sci Ser III 296, 131-136

Arnold G, Masson C (1987) Organisation fonctionnelle du lobe antennaire de l'abeille ouvrière Apis mellifica ligustica $\mathrm{L}$ analysée par la méthode au 2-[1-3H] désoxyglucose. $C R$ Acad Sci Ser I/I 305, 271-275

Arnold G, Masson C, Budharugsa S (1985) Comparative study of the antennal lobes and their afferent pathway in the worker bee and the drone (Apis mellifica L). Cell Tissue Res 242, 593-605

Arnold G, Denizot JP, Masson C (1987) Immunocytochemical demonstration of GABA in the honeybee brain. Bull Soc Zool Fr 111 , 32

Astic L, Saucier D (1983) Ontogenesis of the functional activity of guinea-pig olfactory bulb: autoradiographic study with the 2deoxyglucose method. Dev Brain Res 10, 257-263

Bitterman ME, Menzel R, Fietz A, Schaffer S. (1983) Classical conditioning of proboscis extension in honey bees (Apis mellifera). J Comp Psychol 97(2), 107-119

Blight MM, Hick JA, Pickett JA, Smart LE, Wadhams LJ, Woodcock CM (1992) Volatile plant metabolites involved in host plant recognition by the cabbage seed weevil Ceuthorhynchus assimilis Payk. In: Proc 8th Int Symp InsectPlant Relationships (Menken SBJ, Visser JH, Harrewijn $P$, eds) Kluwer Academic Publ BV, Wageningen, 105-106

Brandon JG, Coss RG (1982) Rapid dendritic spine stem shortening during one-trial learning: the honeybee's first orientation flight. Brain Res 252, 51-61

Coles JA (1989) Functions of glial cells in the retina of the honeybee drone. Glia 2, 1-9

Chase $\mathrm{R}$ (1985) Responses to odors mapped in snail tentacle and brain by ${ }^{14} \mathrm{C}-2$ deoxyglucose autoradiography. J Neurosci 5 , 2930-2939

Coss RG, Brandon JG, Globus A (1980) Changes in morphology of dendritic spines on honeybee calycal interneurons associated with cumulative nursing and foraging experiences. Brain Res 192, 49-59

De Jong R, Visser JH (1988) Integration of olfactory information in the Colorado potato beetle brain. Brain Res 447, 10-17

Derby CD, Ache BW (1984) Quality coding of a complex odorant in an invertebrate. J Neurophysio/ 51, 906-924.

Erber J (1981) Neural correlates of learning in the honeybee. Trends Neurol Sci 4, 270-273 
Erber J, Masuhr T, Menzel R (1980) Localization of short-term memory in the brain of the honeybee. Physiol Entomol 5, 343-358 Erickson (1973) Parallel "population" neural coding in feature extraction. In: The Neurosciences: 3rd Study Program (FO Schmitt et al, eds) Cambridge MIT Press, MA, 155-169

Erickson (1973) Parallel "population" neural coding in feature extraction. In: The neurosciences: 3rd study program (FO Schmitt et al, eds). Cambridge MIT Press, 155-169

Esslen J, Kaissling KE (1976) Zahl und Verteilung antennaler Sensillen bei der Honigbiene. Zoomorphologie 83, 227-251

Etievant $P$, Azar $M$, Pham-Delègue MH, Masson $C$ (1984) Isolation and identification of volatile constituents of sunflowers (Helianthus annuus L). J Agric Food Chem 32, 503509

Flanagan D, Mercer A (1989a) Morphology and response characteristics of neurones in the deutocerebrum of the brain in the honeybee Apis mellifera. J Comp Physiol 164, 483-494

Flanagan D, Mercer A (1989b) An atlas and 3-D reconstruction of the antennal lobe in the worker honeybee, Apis mellifera. Int $J$ Insect Morphol Embryol 18, 145-159.

Fonta C, Pham-Delègue MH, Marilleau R, Masson $C$ (1985) Rôle des nectars de tournesol dans le comportement des insectes pollinisateurs et analyse qualitative et quantitative des éléments glucidiques de ces secrétions. Acta Oecol Oecol Applic 6, 175-186

Fonta C, Sun XJ, Costa J, Masson C (1989) Processing of odorous signals by the antennal lobe neurons of the honeybee. In: Neural Mechanisms of Behavior (Erber J, Menzel R, Pflüger HJ, Todt $D$, eds) Thieme Verlag, Stuttgart, NY, 208

Fonta C, Sun XJ, Masson C (1991) Cellular analysis of odour integration in the honeybee antennal lobe. In: Behaviour and Physiology of Bees (Goodman LJ, Fisher RC, eds) AB Int, Wallingford, UK, 227-241

Fonta C, Sun XJ, Masson C (1993) Morphology and Spatial distribution of bee antennal lobe interneurones responsive to odours. Chem Senses 18 (2), 101-119

Free JB (1965) The allocation of duties among worker honeybees. Proc Symp Zool Soc (Lond) 14, 39-59
Freund DE, Furgala B (1982) Effect of pollination by insects on the seed set and yield of ten oilseed sunflower cultivars. Am Bee $J 9$, 648-652

Frisch K von (1919) Über den Geruchsinn der Bienen und seine blütenbiologische Bedeutung. Zool Jahbr Physiol 37-238

Frisch $\mathrm{K}$ von (1967) The Dance Language and Orientation of Bees. The Belknap Press/ Harvard Univ Press, Cambridge, MA, $566 p$

Gascuel J, Masson C (1987) Influence of olfactory deprivation on synapse frequency in developing antennal lobe of the honeybee Apis mellifera L. Neurosci Res Commun 1, 173180

Gascuel J, Masson C (1991a) Neural plasticity of the developing system of the honeybee. In: Behaviour and Physiology of Bees (Goodman LJ, Fisher RC, eds) CAB Int, Wallingford, UK, 242-252

Gascuel J, Masson C (1991b) A quantitative electron microscopy study of the antennal lobe of the honeybee. Tissue Cell 23, 341355

Gascuel J, Masson C (1991c) Developmental study of afferented and deafferented bee antennal lobes. J Neurobio/ $22,795-810$

Gascuel J, Masson C, Beadle DJ (1991) The morphology and ultrastructure of antennal lobe cells from pupal honeybees (Apis mellifera) growing in culture. Tissue Cell 23, 547559

Getz WM, Smith KB (1987) Olfactory sensitivity and discrimination of mixtures in the honey bee Apis mellifera. J Comp Physiol A 160, 239-246

Getz WM, Chapman RF (1991) An odor perception model with application to kin recognition in social insects. Int J Neurosci 32, 963-978

Getz WM, Smith KB (1991) Olfactory perception in honeybees: concatenated and mixed odorant stimuli, concentration, and exposure effects. J Comp Physiol A 169, 215-230

Getz WM, Akers P (1993) Olfactory response characteristics and tuning structure of placodes in the honey bee Apis mellifera. Apidologie 24 (3) 195-217

Hertel $H(1982)$ The effect of spectral light deprivation on the spectral sensivity of the honey bee. J Comp Physiol 147, 365-369 
Hertel $H$ (1983) Change of synapse frequency in certain photoreceptors of the honeybee after chromatic deprivation. J Comp Physiol 151, 477-482

Holley A, Mac Leod P (1977) Transduction et codage des informations olfactives chez les vertébrès. J Physiol 73, 725-828

Homberg $U$ (1984) Processing of antennal information in extrinsic mushroom body neurons of the bee brain. J Comp Physiol A 154, 825836

Hudson R, Distel H (1988) Functional regeneration of primary olfactory connections in newborn rabbits. In: 8th Cong ECRO, Coventry, UK, 39

Jourdan F, Duveau A, Astic L, Holley A (1980) Spatial distribution of $\left[{ }^{14} \mathrm{C}\right]$. 2-deoxyglucose uptake in the olfactory bulbs of rats stimulated with 2 different odours. Brain Res 188, 139-154

Kauer (1987) Coding in the olfactory system. In : Neurobiology of Taste and Smell (Finger TE, Silver WC, eds), John Wiley and Sons, New York, 205-227

Kerszberg M, Masson C (1990) Origins of oscillatory and chaotic states in the olfactory system. In: Proc ECRO Minisymp Development and Plasticity in the Olfactory System. Luminy, $p 21$

Koltermann R (1969) Lern- und Vergessenprozesse bei der Honigbiene-aufgezeit anhand von Duftdressuren. Z Vgl Physiol 63, 310334

Koltermann R. (1973) Rassen-bzw artspezifische Duftbewertung bei der Honigbiene und ölogische Adaptation. J Comp Physiol 85, 327-360

Kolmes SA (1985) A quantitative study of the division of labour among worker honey bees. $Z$ Tierpsychol 68, 287-302

Kolmes SA, Winston ML (1988) Division of labour among worker honey bees in demographically manipulated colonies. Insectes Soc 35, 262-270

Kramer $E$ (1976) The orientation of walking honey bees in odour fields with small concentration gradients. Physiol Entomol 1, 27-37

Lacher $V$ (1964) Elektrophysiologische Untersuchungen an einzelnen Rezeptoren für Geruch, Kohlendioxyd, Luftfeuchtigkeit und Temperatur auf den Antennen der Arbeits- biene und der Drone (Apis mellifica). $Z$ Vgl Physiol 48, 587-623

Loper GM, Waller GD, Berdel RL (1974) Olfactory screening of alfalfa clones for uniform honeybee selection. Crop Sci 14, 120-122

Marfaing P, Rouault J, Laffort P (1989) Effect of the concentration and nature of olfactory stimuli on the proboscis extension of conditioned honey bees Apis mellifica ligustica. $J$ insect Physiol 35, 949-955

Masson C (1977) Central olfactory pathways and plasticity of responses to odorous stimuli in insects. In: Olfaction and Taste VI (Le Magnen J, Mac Leod P eds) IRL, London, 305-314

Masson C (1983) Rôle des médiateurs chimiques d'origine animale et végétale dans la pollinisation. In: $C R 5^{e}$ Symp Int Pollinisation (INRA ed) 25-37

Masson C (1988) Approche neurobiologique et communication chimique. Ann Soc Entomol Fr 24, 439-445

Masson C, Arnold G (1984) Ontogeny, maturation and plasticity of the olfactory system in the worker bee. J insect Physiol 30, 7-14

Masson C, Arnold G (1987) Organization and plasticity of the olfactory system of the honeybee Apis mellifera. In: Neurobiology and Behavior of Honeybees (Menzel R, Mercer A eds) Springer, NY, 280-295

Masson C, Kerszberg M (1991) Odour encoding by the bee antennal lobe neurons: a problem of functional adaptation. In: Neuromodulation, Learning and Memory in Invertebrates. Eur Sci Networks R Menzel organizer, Berlin, 30

Masson C, Mustaparta H (1990) Chemical information processing in the olfactory system of insects. Physiol Rev 70, 199-245

Mauelshagen (1990) An identified neuron in the honeybee brain-a correlate for olfactory ? $/ \mathrm{m}$ : Brain-Perception-Cognition (Elsner N, Roth $G$, eds) Proc 18th Gottingen Neurobiol Conf, Georg Thieme, NY, 430

Maulshagen J, Greggers U (1993) Experimental access to associative learning in honeybees. Apidologie 24 (3), 249-266

Menzel R (1967) Untersuchungen zum Erlernen von Spektralfarben durch die Honigbiene (Apis mellifera). Z Vgl Physiol 56, 22-62

Menzel R (1983) Neurobiology of learning and memory: the honey bee as a model system. Naturwissenschaften 70, 504-511 
Menzel R (1985) Learning in honey bees in an ecological and behavioral context. In: Experimental Behavioral Ecology (Hölldobler B, Lindauer $M$, eds) Gustav Fischer Verlag, Stuttgart, 55-74

Menzel R (1993) Associative learning in honeybees. Apidologie 24 (3), 157-168

Menzel R, Erber J, Masuhr T (1974) Learning and memory in the honeybee. In: Experimental Analysis of Insect Behaviour (BartonBrowne L, ed) Springer, Berlin, 195-217

Menzel R, Hammer M, Braun G, Mauelshagen J Sugawa M (1991) Neurobiology of learning and memory in honeybees. In: Behaviour and Physiology of Bees (Goodman LJ, Fisher RC, eds), CAB Int, Wallingford, 323-353

Meredith (1986) Patterned response to odor in mammalian olfactory bulb : the influence of intensity. J Neurophysio/ 3, 572-597

Mobbs PG (1982) The brain of the honey bee Apis mellifera. I. The connections and spatial organization of the mushroom bodies. Phil Trans R Soc Lond Biol 298, 309-354

Mobbs PG (1984) Neural networks in the mushroom bodies of the honeybee. J Insect Physiol 30, 43-58

Nicolas G, Arnold G, Patte F, Masson C (1993) Distribution régionale de l'incorporation de $\left[{ }^{3} \mathrm{H}\right] 2$-désoxyglucose dans le lobe antennaire de l'ouvrière d'abeille. CR Acad Sci Sér III (in press)

Oland LA, Tolbert LP (1988) Effect of the hydroxyurea parallel the effects of radiation in developing olfactory glomeruli in insects. $J$ Comp Neurol 278, 377-387

Panov AA (1961) The structure of the insect brain at successive stages in postembryonic development. 4 . The olfactory center. Entomol Rev 40, 140-145

Pareto A (1972) Die zentrale Verteilung der Fühlerefferenz bei Arbeiterinnen der Honigbiene, Apis mellifera. Z Zellforsch 131, 109140

Parker FD (1981) Sunflower pollination: abundance, diversity and seasonality of bees and their effect on seed yields. J Apic Res 20(1), 49-61

Pham-Delègue MH, Masson C (1985) Analyse par conditionnement associatif du mécanisme de la reconnaissance de sources alimentaires par l'abeille. Bull Soc Entomol Fr 90 , 1216-1223
Pham-Delègue MH, Roger B, Pain J (1982) Variation en fonction de l'âge des ouvrières d'abeilles (Apis mellifica ligustica $L$ ) du pouvoir d'attraction d'un extrait de phéromones royales. Apidologie 13, 143-155

Pham-Delègue MH, Masson C, Bonjean A, Etievant $P$, Marilleau R (1985) Étude des paramètres chimiques impliqués dans la pollinisation du tournesol par les abeilles en production de semences hybrides. $|n: X|$ Conf Int Tournesol. Mar del Plata, Argentina, 559-564

Pham-Delègue $\mathrm{MH}$, Masson $\mathrm{C}$, Etievant $\mathrm{P}$ (1986) Selective olfactory choices of the honeybee among sunflower aromas: a study by coupled associative conditioning and chemical analysis. J Chem Ecol 12, 781-793

Pham-Delègue $\mathrm{MH}$, Etievant $P$, Guichard $E$, Masson C (1989) Sunflower volatiles involved in honeybee discrimination among genotypes and flowering stages. I Chem Ecol 15, 329-343

Pham-Delègue $M H$, Etievant $P$, Guichard E, Marilleau R, Douault $P$, Chauffaille J, Masson C. (1990a) Chemicals involved in bee-plant relationships. J Chem Ecol 16, 3053-3065

Pham-Delègue $\mathrm{MH}$, Le Métayer $\mathrm{M}$, Douault $P$, Masson C (1990b) Age-related foraging behavior in honey bees under artificial conditions. Apidologie 21, 107-114

Pham-Delègue $\mathrm{MH}$, de Jong $\mathrm{R}$, Masson $\mathrm{C}$ (1990c).-Effet de l'âge sur la réponse conditionnée d'extension du proboscis chez l'abeille domestique. CR Acad Sci Ser III 310, 527-532

Pham-Delègue $\mathrm{MH}$, Masson $\mathrm{C}$, Etievant $\mathrm{P}$ (1991a) Allelochemicals mediating foraging behaviour: the bee-sunflower model. $/ n$ : $\mathrm{Be}$ haviour and Physiology of Bees (Goodman $\mathrm{LJ}$, Fisher RC, eds) CAB Int, Wallingford, 163-184

Pham-Delègue $\mathrm{MH}$, Trouiller J, Bakchine $\mathrm{E}$, Roger B, Masson C (1991b) Age dependency of worker bee response to queen pheromone in a four-armed olfactometer. Insectes Soc 38, 283-292

Pham-Delègue $M H$, Blight MM, Le Metayer $M$, Marion-Poll F, Picard AL, Pickett JA, Wadhams LJ, Woodcock CM (1992) Plant chemicals involved in honeybee-rapeseed relationships: behavioral, electrophysiological and chemical studies. In: Proc 8th int Symp In- 
sect-Plant Relationships (Menken SBJ, Visser JH, Marrewijn $P$, eds) Kluwer Academic Publ BV, Wageningen, 129-130

Pham-Delègue $M H$, Trouiller $J$, Caillaud $M$, Roger B, Masson C (1993) Effect of queen pheromone on worker bees of different ages: behavioural and electrophysiological responses. Apidologie 24 (3), 267-281

Pham-Delègue MH, Bailez O, Blight MM, Masson C, Picard-Nizon AL, Wadhams LJ (1993) Behavioural discrimination of oilseed rape volatiles by the honeybee. Chemical Senses 18 (5) (in press)

Radford BJ, Rhodes JW (1978) Effect of honeybee activity on the cross-pollination of malesterile sunflowers. Queens J Agric Anim Sci 35(2), 153-157

Robacker DC, Flottum PK, Sammataro D, Erickson EH (1982) Why soybeans attract honey bees? Am Bee J 7, 481-519

Robinson GE (1987) Alarm pheromone perception in the honey bee, evidence for division of labor based on hormonally modulated response thresholds. J Comp Physiol 160A, 613-619

Rodrigues $V$ (1988) Spatial coding of olfactory information in the antennal lobe of Drosophila melanogaster. Brain Res 453, 299-307

Rodrigues V, Buchner E (1984) 3H 2deoxyglucose mapping of odor-induced neuronal activity in the antennal lobes of Drosophila melanogaster. Brain Res 324, 374378

Royet JP, Sicard G, Souchier C, Jourdan F (1987) Specificity of spatial patterns of glomerular activation in the mouse olfactory bulb: computer-assisted image analysis of 2deoxyglucose autoradiograms. Brain Res $417,1-11$

Sakagami SF (1953) Untersuchungen über die Arbeitsteilung in einem Zwergvolk der Honigbiene. Beitrag zur Biologie des Bienenvolkes, Apis mellifera L. Jpn J Zool 11, 117-185

Schwarz R (1955) Über die Riechscharfe der Honigbiene. Z Vgl Physio/ 37, 180-210

Seeley TD (1982) Adaptive significance of the age polyethism schedule in honeybee colonies. Behav Ecol Sociobiol 11, 287-292

Selzer R (1981) The processing of a complex food odor by antennal olfactory receptors of Periplaneta americana. J Comp Physiol 144, 509-519
Sinclair (1984) The Biochemistry and Physiology of the Lemon and Other Citrus Fruits. Univ California, Div Agric Nat Res, Oakland CA 94608-1239

Slessor KN, Kaminski LA, King GGS, Borden $\mathrm{JH}$, Winston ML (1988) Semiochemical basis of the retinue response to queen honey bees. Nature (Lond) 332, 354-356

Smith BH (1991) The olfactory memory of the honeybee Apis mellifera. I. Odorant modulation of short- and intermediate-term memory after a single-trial conditioning. $J$ Exp Biol 161, 367-382

Smith BH, Menzel R (1989) The use of electromyogram recordings to quantify odor discrimination in the honeybee. J Insect Physiol 35, 369-375

Sokoloff L, Reivich M, Kennedy C, Des Rosiers MM, Patlak CS, Pettigrew KD, Sakudara O, Shinihara M (1977) The ${ }^{14} \mathrm{C}$-deoxyglucose method for the measurement of local cerebral utilization: theory, procedure and mammal values in the conscious and anesthetized albino rat. J Neurochem 28, 897-916

Stewart WB, Kauer JS, Shepherd GM (1979) Functional organization of rat olfactory bulb analysed by the 2-deoxyglucose method. J Comp Neurol 185, 715-734

Sun XJ (1991) Caractérisation électrophysiologique et morphologique des neurones olfactifs du lobe antennaire de l'abeille, Apis mellifera (Thèse Doct Sci, Univ Paris-Sud, Orsay), $184 \mathrm{p}$

Sun XJ, Fonta C, Masson C (1993) Odour quality processing by bee antennal lobe interneurones. Chemical Senses 18 (4) (in press)

Takeda K (1961) Classical conditioned response in the honey bee. J Insect Physio/ 6, 168-179

Thiery D, Bluet JM, Pham-Delègue MH, Etievant $P$, Masson C (1990) Sunflower aroma detection by the honeybee: study by coupling gas chromatography and electroantennography. $J$ Chem Ecol 16, 701-711

Tsacopoulos M, Evêquoz-Mercier V, Perrottet $P$, Buchner E (1988) Honeybee retinal glial cells transform glucose and supply the neurons with metabolic substrate. Proc Natl Acad USA 85, 8727-8731

Vareschi E (1971) Duftunterscheidung bei der Honigbiene-Einzelzell Ableitungen und Verhaltensreaktionen. $Z$ Vgl Physiol 75, 143173 
Waller GD, Loper GM, Berdel RL (1974) Olfactory discrimination by honeybees of terpenes identified from volatiles of alfalfa flowers. $J$ Apic Res 13(3), 191-197

Wenner AM, Johnson DL (1967) Honeybees: do they use direction and distance information provided by their dances? Science 158, 1072-1077

Winston ML, Fergusson LA (1985) The effect of worker loss on temporal caste structure in colonies of the honeybee (Apis mellifera $L$ ). Can J Zool 63, 777-780

Withers GS, Fahrbach SE, Robinson GE (1992) Neuroanatomical plasticity is associated with division of labor among adult worker honey bees. In: 3rd Int Congr Neuroethol. Montreal, Quebec, 1992

Witthöft W (1967) Absolute Anzahl und Verteilung der Zellen im Hirn der Honigbiene. Z Morphol Tiere 61, 160-184 